\title{
The Effects of Previous Renal Stone Surgery on Percutaneous Nephrolithotomy Outcomes
}

\section{Geçirilmiş Böbrek Taşı Cerrahisinin Perkütan Nefrolitotomi Sonuçları Üzerine Etkileri}

\author{
Joshgun Huseynov (1), Nadir Kalfazade ®, Ekrem Guner (® \\ Department of Urology, University of Health Sciences, Dr. Sadi Konuk Training and Research Hospital, Istanbul, Turkey \\ Cite as: Huseynov J, Kalfazade N, Guner E. The effects of previous renal stone surgery on percutaneous nephrolithotomy outcomes. Grand J Urol 2021;1(1):18-21. \\ Submission date: 03 December 2020 \\ Acceptance date: 09 December 2020 \\ Online first: 05 January 2021 \\ Publication date: 20 January 2021 \\ Corresponding Author: Ekrem Guner / University of Health Sciences, Dr. Sadi Konuk Training and Research Hospital, Department of Urology, Bakirkoy, Istanbul, Turkey \\ ekremguner@yahoo.com ORCID: 0000-0002-4770-7535
}

\begin{abstract}
Objective: We aimed to compare outcomes of percutaneous nephrolithotomy (PNL) surgery in patients who had and had not undergone renal stone surgery before PNL.

Material and Methods: We retrospectively analyzed the medical records of all patients who underwent PNL in our department between 2010 and 2019. Examined parameters consisted of patient demographics, medical and surgical history, stone size, stone density, stone site, estimated intraoperative blood loss, duration of operation, hospital stay and stone-free status.

Results: A total of 193 patients were included the study. The mean age of the patients was $45 \pm 13$ years. The mean duration of surgery was $69 \pm 11.5$ minutes. The mean stone area was $720.2 \pm 600.4 \mathrm{~mm} 2$ and the mean stone attenuation was $982.8 \pm 327.7 \mathrm{HU}$. The mean postoperative hemoglobin decrease was $1.8 \pm 1.3 \mathrm{~g} / \mathrm{dL}$. 66 patients had previous stone surgery including open stone surgery, PNL and retrograde intrarenal surgery (RIRS). There was no statistically significant difference between patients who had and had not previousşy undergone renal stone surgery in terms of age, gender, body mass index and stone area. Operative time, estimated intraoperative blood loss, postoperative hemoglobin decreases and hospital stay were comparable between patients who had, and hed not undergone previous renal stone surgery. Stone-free rate was significantly higher in primary PNL patients compared to patients with a history of renal stone surgery $(92.1 \%$ vs $77.3 \%, \mathrm{p}=0.006)$.

Conclusion: PNL has a similar complication rate in patients with and without previous kidney stone surgery. However, achieving stone-free status may be challenging in patients with a history of ipsilateral renal stone surgery.
\end{abstract}

Keywords: percutaneous nephrolithotomy, previous renal stone surgery, stone-free status

Öz

Amaç: Perkütan Nefrolitotomi (PNL) öncesi böbrek taşı ameliyatı geçirmiş ve geçirmemiş hastalarda PNL ameliyatının sonuçlarını karşılaştırmayı amaçladık.

Gereç ve Yöntemler: Bölümümüzde 2010-2019 yılları arasında PNL yapılan tüm hastaların tıbbi kayıtlarını retrospektif olarak inceledik. İncelenen parametreler; hasta demografisi, medikal ve cerrahi geçmiş, taş boyutu, taş yoğunluğu, taş bölgesi, tahmini intraoperatif kanama miktarı, ameliyat süresi, hastanede kalış süresi ve taşsızlık durumundan oluşmaktadır.

Bulgular: Çalışmaya toplam 193 hasta dahil edildi. Hastaların ortalama yaş1 $45 \pm 13$ yıldı. Ortalama ameliyat süresi $69 \pm 11.5$ dakika idi. Ortalama taş alanı 720,2 $\pm 600,4 \mathrm{~mm} 2$ ve ortalama taş atenüasyonu 982,8 $\pm 327,7 \mathrm{HU}$ idi. Ortalama postoperatif hemoglobin azalması $1.8 \pm 1.3 \mathrm{~g} / \mathrm{dL}$ idi. $66 \mathrm{hasta}$ daha önce açık taş cerrahisi, PNL ve retrograt intrarenal cerrahi (RIRS) dahil olmak üzere taş ameliyatı geçirmişti. Daha önce böbrek taşı ameliyatı geçirmiş ve geçirmemiş hastalar arasında yaş, cinsiyet, vücut kitle indeksi ve taş alanı açısından istatistiksel olarak anlamlı farklılık bulunmadı. Daha önce böbrek taşı ameliyatı geçirmiş ve geçirmemiş hastalar arasında ameliyat süresi, tahmini intraoperative kanama miktarı, ameliyat sonrası hemoglobin azalması ve hastanede kalış süresi benzerdi. Primer PNL hastalarında daha önce böbrek taşı ameliyatı geçirmiş hastalara göre taşsızlık oranı anlamlı olarak yüksekti (\% 92.1'e karş1\% 77.3, p=0.006).

Sonuç: Daha önce böbrek taşı cerrahisi geçiren ve geçirmeyen hastalarda PNL benzer komplikasyon oranına sahiptir. Bununla birlikte, ipsilateral böbrek taşı cerrahisi öyküsü olan hastalarda taşsızlık durumuna ulaşmak daha zor olabilir.

Anahtar Kelimeler: perkütan nefrolitotomi, geçirilmiş böbrek taşı cerrahisi, taşsızlık durumu 


\section{Introduction}

Urolithiasis is a major health problem all around the world with an estimated incidence of $11.1 \%$ in Turkey [1]. Urinary stone disease is related to many factors such as genetics, dietary habits, body mass index, fluid intake, occupation, geography and climate [2]. Management of stone disease includes medical treatment, minimal invasive treatment modalities such as extracorporeal shock wave lithotripsy and surgical treatment like ureterorenoscopy (URS), retrograde intrarenal surgery (RIRS) and percutaneous nephrolithotomy (PNL) [3].

PNL has been utilized more than 30 years in renal stone disease treatment. Parallel to the developments in technology and refinement of endourological equipment's several modifications of PNL such as supine or prone, mini or micro has been offered during the recent years.

PNL is also not without complications. Perioperative bleeding is one of the main complications of PNL, and it is not always possible to achieve stone-free status after PNL. Several factors have been proposed to effect surgical outcomes of PNL. In this study, we aimed to compare outcomes of PNL surgery in patients who had, and had not undergone prior renal stone surgery before PNL and who did not have.

\section{Materials and Methods}

Local ethics committee approval was obtained prior to study (Approval Number: 2020/506). We retrospectively analyzed the medical records of all patients who underwent PNL in our department between 2010 and 2019. Both male and female patients above 18 years of age who underwent PNL were included the study. Patients with bleeding diathesis or history of renal malignancy were excluded from the study. Examined parameters consisted of patient demographics, medical and surgical history, stone size, stone density, stone site, estimated intraoperative blood loss, operative time, hospital stay and stone-free status. Stone area was calculated by multiplying two dimensions of the stone.

\section{Statistical analysis}

Statistical analysis was performed using IBM SPSS Statistics for Windows v.21.0 (IBM Corp., Armonk, NY). Mean \pm standard deviation and median values were used to express quantitative measurements. Qualitative measurements were expressed as numbers and percentages. Mann-Whitney $U$ test was used to compare numerical values between independent groups. The level of statistical significance was set at $\mathrm{P}<0.05$.

\section{Results}

A total of 193 participants including 127 male and 66 female patients were included in the study. The mean age of the patients was $45 \pm 13$ years. The mean duration of surgery was $69 \pm 11.5$ minutes. Seventy-nine (40.9\%) right-, and 114(59.1\%) left-sided stones were operated. The mean stone volume was $720.2 \pm 600.4$ $\mathrm{mm}^{3}$ and the mean stone attenuation was $982.8 \pm 327.7 \mathrm{HU}$. The mean preoperative hemoglobin level was $14.2 \pm 1.7 \mathrm{mg} / \mathrm{dL}$. The mean postoperative decrease in hemoglobin levels was $1.8 \pm 1.3$ $\mathrm{g} / \mathrm{dL}$. Sixty-six patients had previous stone surgery including

Table 1. Patient demographics, stone and operation characteristics

\begin{tabular}{|c|c|c|c|c|c|}
\hline \multicolumn{2}{|c|}{ Variable } & Total $(n=193)$ & $\begin{array}{c}\text { Primary PNL } \\
(n=127)\end{array}$ & $\begin{array}{l}\text { Previous ipsilateral } \\
\text { renal surgery }(n=66)\end{array}$ & Pvalue \\
\hline \multicolumn{2}{|c|}{ Age (years) } & $45 \pm 13$ & $44.4 \pm 13.2$ & $46.3 \pm 12.6$ & 0.34 \\
\hline \multirow{2}{*}{ Gender } & Male & 127 & 87 & 40 & \multirow{2}{*}{0.33} \\
\hline & Female & 66 & 40 & 26 & \\
\hline \multicolumn{2}{|c|}{$\operatorname{BMI}\left(\mathrm{kg} / \mathrm{m}^{2}\right)$} & $27.5 \pm 3.5$ & $27.6 \pm 3.6$ & $27.4 \pm 3.4$ & 97 \\
\hline \multicolumn{2}{|c|}{ Stone area $\left(\mathrm{mm}^{2}\right)$} & $720.2 \pm 600.4$ & $651.3 \pm 531.6$ & $854.7 \pm 701.2$ & 0.62 \\
\hline \multicolumn{2}{|c|}{ Stone attenuation (HU) } & $982.8 \pm 327.7$ & $1018.2 \pm 339.7$ & $915.2 \pm 294.3$ & 0.02 \\
\hline \multicolumn{2}{|c|}{ Operative time (min) } & $69 \pm 11.5$ & $68.4 \pm 11.6$ & $70.1 \pm 11$ & 0.41 \\
\hline \multicolumn{2}{|c|}{ Estimated blood loss (mL) } & $177.6 \pm 102.9$ & $177.1 \pm 99.4$ & $178.7 \pm 110$ & 0.57 \\
\hline \multicolumn{2}{|c|}{ Preoperative hemoglobin (g/dl) } & $14.2 \pm 1.7$ & $14.3 \pm 1.8$ & $13.8 \pm 1.3$ & 0.02 \\
\hline \multicolumn{2}{|c|}{ Postoperative hemoglobin (g/dl) } & $12.4 \pm 1.9$ & $12.5 \pm 2.1$ & $12.2 \pm 1.6$ & 0.22 \\
\hline \multicolumn{2}{|c|}{ Hemoglobin decrease $(\mathrm{g} / \mathrm{dl})$} & $1.8 \pm 1.3$ & $1.8 \pm 1.4$ & $1.7 \pm 1.2$ & 0.5 \\
\hline \multicolumn{2}{|c|}{ Hospital stay (days) } & $3.5 \pm 1.5$ & $3.6 \pm 1.5$ & $3.4 \pm 1.4$ & 0.56 \\
\hline \multicolumn{2}{|c|}{ Stone- free rates } & $87 \%$ & $92.1 \%$ & $77.3 \%$ & 0.006 \\
\hline
\end{tabular}

BMI: body mass index; HU: Hounsfield units; PNL: percutaneous nephrolithotomy 
open stone surgery, PNL and retrograde intrarenal surgery (RIRS). There was no statistically significant difference between patients who had, and had not previously undergone renal stone surgery in terms of age, gender, body mass index and stone burden. Stone attenuation was significantly higher in primary PNL patients $(\mathrm{p}=0.02)$. Operative time, estimated intraoperative blood loss, postoperative decrease in hemoglobin levels and hospital stay were comparable between patients who had, and had not previously undergone renal stone surgery. Stone-free rate was significantly higher in primary PNL patients compared to patients with a history of renal stone surgery $(92.1 \%$ vs $77.3 \%, p=0.006$ (Table 1).

\section{Discussion}

PNL is the choice of treatment of renal stones particularly larger than $2 \mathrm{~cm}$. PNL is not without complications and achieving stone-free status depends on several factors as patient and stone characteristics and surgical experience. To date several studies have been conducted to determine the effects of previous renal surgeries on PNL outcomes [4-6]. Despite the emmense literature available on this issue, relevant definitive recommendations are lacking.

In a study by Falahatkar et al. [7], researchers aimed to determine the effects of previous open renal surgery on PNL complications and related outcomes. The authors did not find any significant differences between mean hospital stay (85.88 \pm 17.25 vs $80.2 \pm 17.71$ hours $)$, mean operative time $(75.4 \pm 17.2$ vs $67.4 \pm 26.2$ minutes), bleeding requiring transfusion $(11.1 \%$ vs $11.8 \%$ ), postoperative fever $(33.3 \%$ vs $26.5 \%)$ and stonefree status ( $88.9 \%$ vs $79.4 \%$ ) who had and had not previously undergone ipsilateral open renal surgery. Similar to this study, we did not find any differences in various parameters except stone-free status between primary PNL patients and patients who had previously undergone renal stone surgery. Stone-free rate was significantly higher in our patient cohort.

In a recent study, Basnet et al. [8] investigated the effects of open renal surgery on PNL results. Their study included 512 patients who had undergone primary PNL and 106 patients who had ipsilateral open stone surgery, previously. There was no difference between those two groups in terms of patient characteristics (age gender, body mass index), and stone features like stone burden, density. location and being staghorn. They reported similar hospital stay (3.29 \pm 1.21 vs $3.48 \pm 1.05$ days) and stone-free rates $(83.33 \%$ vs $82.08 \%$ ) between primary PNL and previous open surgery groups whilst higher complication rates in previous open renal surgery group $(27.45 \%$ vs $38.68 \%$, $\mathrm{p}=0.02$ ). The most frequent postoperative complications were fever and Clavien Grade < IV complications [8]. As mentioned before our stone-free rate in patients with previous renal stone surgery was $77.3 \%$ and significantly lower than that in primary PNL patients $(87 \%)$.

Ozgor et al. [9] investigated the effect of both previous PNL or open renal surgery on PNL outcomes. Their study included 1529 patients who underwent primary PNL, 131 patients with a history of previous PNL and 410 patients with a history of open renal surgery. The authors reported the highest stone-free rate $(81.6 \%)$ in primary PNL patients. They also found that need of angioembolization following PNL was highest with a rate of $2.2 \%$ in patients with a history of open renal surgery. In contrast with the aforementioned studies, they reported similar hospitalization times, postoperative decreases in hemoglobin levels, and operative times. In concordance with Ozgor et al. [9] we did not find any difference between duration of hospital stay, operative time and postoperative hemoglobin decrease in our patient cohort.

In a meta-analysis by $\mathrm{Hu}$ et al. [10] including 17 retrospective studies involving 4833 procedures, it was concluded that PNL in patients with a history of open surgery was associated with greater hemoglobin decrease, higher risk of events requiring angiographic embolization and auxiliary procedures and also longer operative time.

Our study is not also without limitations. First of all, this is a retrospective study conducted with a relatively small number of patients. Retrospective nature of the study might subject to selection bias. Also, as a result of being a training and research hospital PNL surgeries were performed by several surgeons which might also affect surgical outcomes.

\section{Conclusion}

PNL has similar complication rates in patients who had and had not undergone kidney stone surgery. However, achieving stone-free status may be challenging in patients with a history of ipsilateral renal stone surgery.

Ethics Committee Approval: The study was approved by University of Health Sciences, Dr. Sadi Konuk Training and Research Hospital Ethical Committee, Bakirkoy, Istanbul, Turkey (Decision No: 2020/506).

Informed Consent: An informed consent was obtained from all the patients.

Publication: The results of the study were not published elsewhere in full or in part in form of abstracts.

Peer-review: Externally peer-reviewed.

Authorship Contributions: Any contribution was not made by any individual not listed as an author. Concept - J.H., E.G.; Design - J.H., N.K., E.G.; Supervision - E.G.; Resources - J.H., N.K.; Materials - J.H., N.K.; Data Collection and/or Processing - J.H., N.K.; Analysis and/or Interpretation - J.H., N.K., E.G.; Literature Search - J.H., N.K., E.G.; Writing - J.H., N.K.; Critical Review - J.H., N.K., E.G.

Conflict of Interest: The authors declare that they have no conflict of interest.

Financial Disclosure: The authors declare that they did not receive any financial support for the realization of this study. Informing: Due to the presence of the name of the journal editor's among the authors, the assessment process of the study was conducted by the guest editor. 


\section{References}

[1] Muslumanoglu AY, Binbay M, Yuruk E, Akman T, Tepeler A, Esen T, et al. Updated epidemiologic study of urolithiasis in Turkey. I: Changing characteristics of urolithiasis. Urol Res 2011;39:309-14. https://doi.org/10.1007/s00240-010-0346-6.

[2] Bartoletti R, Cai T, Mondaini N, Melone F, Travaglini $\mathrm{F}$, Carini $\mathrm{M}$, et al. Epidemiology and risk factors in urolithiasis. Urol Int 2007;79:3-7. https://doi.org/10.1159/000104434.

[3] Zumstein V, Betschart P, Abt D, Schmid HP, Panje CM, Putora PM. Surgical management of urolithiasis - A systematic analysis of available guidelines. BMC Urol 2018;18:25. https://doi.org/10.1186/s12894-018-0332-9.

[4] Resorlu B, Kara C, Senocak C, Cicekbilek I, Unsal A. Effect of previous open renal surgery and failed extracorporeal shockwave lithotripsy on the performance and outcomes of percutaneous nephrolithotomy. J Endourol 2010;24:13-6. https://doi.org/10.1089/end.2009.0291.

[5] Li ZL, Deng Q, Chong T, Zhang P, Li HC, Li HL, et al. Predictors of clinical outcome after minimally invasive percutaneous nephrolithotomy for renal calculus. Urolithiasis 2015;43:355-61.

https://doi.org/10.1007/s00240-015-0771-7.
[6] Yesil S, Ozturk U, Goktug HNG, Tuygun C, Nalbant I, Imamoglu MA. Previous open renal surgery increased vascular complications in percutaneous nephrolithotomy (PCNL) compared with primary and secondary PCNL and extracorporeal shock wave lithotripsy patients: A retrospective study. Urol Int 2013;91:331-4. https://doi.org/10.1159/000351968.

[7] Falahatkar S, Panahandeh Z, Ashoori E, Akbarpour M, Khaki N. What is the difference between percutaneous nephrolithotomy in patients with and without previous open renal surgery? J Endourol 2009;23:1107-10. https://doi.org/10.1089/end.2008.0630.

[8] Basnet RB, Shrestha A, Shrestha PM, Joshi BR. Outcomes of Percutaneous Nephrolithotomy in Patients with Previous Ipsilateral Open Renal Stone Surgery. J Nepal Health Res Counc 2020;18:277-81. https://doi.org/10.33314/jnhrc.v18i2.2285.

[9] Ozgor F, Kucuktopcu O, Sarılar O, Toptas M, Simsek A, Gurbuz ZG, et al. Does previous open renal surgery or percutaneous nephrolithotomy affect the outcomes and complications of percutaneous nephrolithotomy. Urolithiasis 2015;43:541-7. https://doi.org/10.1007/s00240-015-0798-9.

[10] Hu H, Lu Y, Cui L, Zhang J, Zhao Z, Qin B, et al. Impact of previous open renal surgery on the outcomes of subsequent percutaneous nephrolithotomy: A meta-analysis. BMJ Open 2016;6:e010627. https://doi.org/10.1136/bmjopen-2015-010627. 